\title{
LUT
}

University

\section{Corporate Social Responsibility (CSR) Priorities in the Small and Medium Enterprises (SMEs) of the Industrial Sector of Sialkot, Pakistan}

\author{
Awan Usama, Khattak Amira, Kraslawski Andrzej
}

This is a Author's accepted manuscript (AAM) version of a publication

published by Springer, Berlin, Heidelberg

in Corporate Social Responsibility in the Manufacturing and Services Sectors. EcoProduction (Environmental Issues in Logistics and Manufacturing)

DOI: 10.1007/978-3-642-33851-9_15

Copyright of the original publication: (C) 2018 Springer Nature Switzerland AG

Please cite the publication as follows:

Awan U., Khattak A., Kraslawski A. (2019) Corporate Social Responsibility (CSR) Priorities in the Small and Medium Enterprises (SMEs) of the Industrial Sector of Sialkot, Pakistan. In: GolinskaDawson P., Spychała M. (eds) Corporate Social Responsibility in the Manufacturing and Services Sectors. EcoProduction (Environmental Issues in Logistics and Manufacturing). Springer, Berlin, Heidelberg

This is a parallel published version of an original publication. This version can differ from the original published article. 


\section{Metadata of the chapter that will be visualized in SpringerLink}

\begin{tabular}{|c|c|c|}
\hline Book Title & \multicolumn{2}{|c|}{ Corporate Social Responsibility in the Manufacturing and Services Sectors } \\
\hline \multicolumn{3}{|l|}{ Series Title } \\
\hline Chapter Title & \multicolumn{2}{|c|}{$\begin{array}{l}\text { Corporate Social Responsibility (CSR) Priorities in the Small and Medium Enterprises (SMEs) of the } \\
\text { Industrial Sector of Sialkot, Pakistan }\end{array}$} \\
\hline Copyright Year & \multicolumn{2}{|l|}{2019} \\
\hline Copyright HolderName & \multicolumn{2}{|c|}{ Springer-Verlag GmbH Germany, part of Springer Nature } \\
\hline \multirow[t]{13}{*}{ Author } & Family Name & Awan \\
\hline & Particle & \\
\hline & Given Name & Usama \\
\hline & Prefix & \\
\hline & Suffix & \\
\hline & Role & \\
\hline & Division & School of Business and Management \\
\hline & Organization & Lappeenranta University of Technology (LUT) \\
\hline & Address & Lappeenranta, Finland \\
\hline & Division & Management Science Department \\
\hline & Organization & COMSATS Institute of Information Technology \\
\hline & Address & Vehari, Pakistan \\
\hline & Email & usama.awan@lut.fi \\
\hline \multirow[t]{10}{*}{ Corresponding Author } & Family Name & Khattak \\
\hline & Particle & \\
\hline & Given Name & Amira \\
\hline & Prefix & \\
\hline & Suffix & \\
\hline & Role & \\
\hline & Division & College of Business Administration \\
\hline & Organization & Prince Sultan University \\
\hline & Address & Riyadh, Saudi Arabia \\
\hline & Email & akhattak@psu.edu.sa \\
\hline \multirow[t]{12}{*}{ Author } & Family Name & Kraslawski \\
\hline & Particle & \\
\hline & Given Name & Andrzej \\
\hline & Prefix & \\
\hline & Suffix & \\
\hline & Role & \\
\hline & Division & Industrial Engineering and Management \\
\hline & Organization & Lappeenranta University of Technology \\
\hline & Address & Lappeenranta, Finland \\
\hline & Division & Department of Process and Environmental Engineering \\
\hline & Organization & Lodz University of Technology \\
\hline & Address & Lodz, Poland \\
\hline
\end{tabular}


The purpose of this research is to explore and understand corporate social responsibility (CSR) priorities in the small and medium enterprises (SMEs) of the industrial sector of Sialkot in Pakistan. The industrial sector of Sialkot is mainly involved in the production and supplying of sports, leather and surgical products for global companies. We used a qualitative approach to explore CSR priorities among SMEs. Informants were identified using purposive sampling. In-depth interviews were conducted with the senior managers, owners and executives of SMEs in the Sialkot industrial sector of Pakistan in three main industries namely, sports, surgical and leather. The findings of the study suggest philanthropy as a key ethical and social priority and CSR dimension supported by SMEs. Main dimensions of CSR in the context of Sialkot industrial sector SMEs were social (philanthropy), economic, legal and environment. In terms of CSR dimensions priorities, differences exist due to the nature of the specific industry and its protocols as data were collected from three different sub industrial sectors within the Sialkot industrial sector. 


\title{
Corporate Social Responsibility (CSR) Priorities in the Small and Medium Enterprises (SMEs) of the Industrial Sector of Sialkot, Pakistan
}

\author{
Usama Awan, Amira Khattak and Andrzej Kraslawski
}

\begin{abstract}
The purpose of this research is to explore and understand corporate social responsibility (CSR) priorities in the small and medium enterprises (SMEs) of the industrial sector of Sialkot in Pakistan. The industrial sector of Sialkot is mainly involved in the production and supplying of sports, leather and surgical products for global companies. We used a qualitative approach to explore CSR priorities among SMEs. Informants were identified using purposive sampling. In-depth interviews were conducted with the senior managers, owners and executives of SMEs in the Sialkot industrial sector of Pakistan in three main industries namely, sports, surgical and leather. The findings of the study suggest philanthropy as a key ethical and social priority and CSR dimension supported by SMEs. Main dimensions of CSR in the context of Sialkot industrial sector SMEs were social (philanthropy), economic, legal and environment. In terms of CSR dimensions priorities, differences exist due to the nature of the specific industry and its protocols as data were collected from three different sub industrial sectors within the Sialkot industrial sector.
\end{abstract}

U. Awan

School of Business and Management, Lappeenranta University of Technology (LUT),

Lappeenranta, Finland

e-mail: usama.awan@lut.fi

U. Awan

Management Science Department, COMSATS Institute of Information Technology, Vehari, Pakistan

A. Khattak $(\bowtie)$

College of Business Administration, Prince Sultan University, Riyadh, Saudi Arabia e-mail: akhattak@psu.edu.sa

A. Kraslawski

Industrial Engineering and Management, Lappeenranta University of Technology, Lappeenranta, Finland

e-mail: Andrzej.Kraslawski@lut.fi

A. Kraslawski

Department of Process and Environmental Engineering, Lodz University of Technology, Lodz, Poland 


\section{Introduction}

AQ1 16

Corporate Social Responsibility (CSR) has gained prominence in the academic research in recent years. According to Business for Social Responsibility (2003), CSR is defined as "achieving commercial success in ways that honour ethical values and respect people, communities, and the natural environment". No doubt CSR is not only becoming a popular trend among large and multinational corporations but also among Small and Medium Enterprises (SMEs) as well. SMEs are critical component and resource for modern days economic activity. SMEs are vital for creating resources for the community including employment opportunities to the community. Similarly, SMEs in the Sialkot industrial sector of Pakistan are contributing to exports, foreign exchange earnings and employment (Khattak and Stringer 2017). SME is defined in the study as a business which varies in flexibility and volatility (Deakins and Freel 1998; Duan et al. 2001); having between 20 and 250 employees and an annual turnover of between Rs. ${ }^{1} 75$ and 400 million (State Bank of Pakistan 2013). Most of the SMEs in Pakistan are very small with limited employment and growth potentials, primary concern being economic survival only. Moreover, most of the firms are owner-managed and supported by family members, lacking the capabilities and resources to deal with the business and social issues (Awan et al. 2017).

The research on the implementation of environmental and social practices is gaining prominence (CSR dimensions) in the academic literature, in particular, in the context of developing countries (See for example Khattak et al. 2015, 2017). Many firms in the developing countries, particularly SMEs, adopt CSR practices mainly for the pragmatic or functional reasons and not as the main motivator or with a clear purpose. SMEs perceive that social and environmental certifications will make them attractive to the buyers for orders purposes because buyers prefer to work with firms undertaking CSR activities (Khattak and Stringer 2017). Engaging in CSR activities has been viewed as a central strategy for survival in the ever changing business environment (Laskar et al. 2016) where reputation of a firm is positively related to the firm's efforts related to CSR activities (Blindheim and Langhelle 2010). Hence, there is a very transactional approach towards engaging in CSR activities by SMEs in the developing countries context where weak legal infrastructure exists regarding social and environmental standards.

A limited number of studies in the developing countries context have been conducted from the CSR perspective, in particular from consumer perspective specifically (see Turyakira 2018) and produced mixed results (Arli and Lasmono 2010). There is a lack of research in developing countries context from CSR perspective and SME perspective (Das and Rangarajan 2017; Hadjimanolis 2017), hence providing researchers with an opportunity to study the CSR from developing countries and SME perspectives. Meaning to explore and understand the CSR activities and priorities in the context of SMEs from developing countries. A number of studies have concentrated on studying the impact of CSR practices on the operations of SMEs and yet very little regard has been given to investigating the relationship between CSR

${ }^{1}$ Pakistani currency termed as Rupee plural Rupees. 
meaning and CSR activities in SMEs in the developing countries' context (Manuere and Phiri 2016). This study attempts to fill a gap in the existing literature and responds to research calls for more insights into firms' s CSR activities from the perspective of managerial employees (Perrini et al. 2007) and from the perspective of SMEs and developing countries' perspectives.

The chapter is structured as follows. First, a literature review has been discussed followed by the research methodology. Findings and discussion section summarizes the main findings of the study and explains how findings are linked to other studies in the literature. The chapter concludes with conclusions and future research directions of the study.

\section{Literature Review}

According to Carroll $(1979,1991)$ and Matten and Moon (2008) components of CSR consists of four core activities: economic, legal, ethical and philanthropic responsibilities. Whereas, Davies and Crane (2010) and Waddock (2004) identifies ethical, legal and economic as core components of any CSR activity. Dahlsrud (2008) studied 37 meanings of CSR and discovered that there are five dimensions of CSR namely, the environmental dimension, the social dimension, the economic dimension, the stakeholder dimension and the voluntariness dimension (Manuere and Phiri 2016). The five dimensions of Dahlsrud (2008) are consistent with the dimensions of CSR given by Carroll (1991) being, economic, legal and ethical because environment falls under both legal in case of obligatory activities and voluntarily (ethical) where actions are not required legally but are results of proactive stance.

The economic responsibilities of a firm are defined as to be productive and profitable and to meet needs of society. Legal responsibilities of business suggest the need for economic responsibilities to be approached within the written law. The ethical responsibilities of business reflect the unwritten codes, norms and values implicitly derived from society and, as such, go beyond the mere legal frameworks. The philanthropic responsibilities of business are discretional in nature and society (Aupperle et al. 1990; Carroll 1979). Philanthropic activities may affect the customers' perceptions and attitudes and affect the reputation of firms positively bringing more profits. Philanthropy is not a function of profit, but it consists of firms both objectives of profit and social reputations (Shiozawa 1995). Philanthropy is related to cash giving basically but the impulse to contribute is based on religious beliefs of managers/owners of SMEs operating in few countries.

SMEs represent a large part of the world economy (Ketola et al. 2009). SMEs are considered job creating platform providing innovative business practices (Laudal 2011). While multinational corporations have contributed formally and are well versed about CSR activities, studies suggest that SMEs tend to be largely unfamiliar with the social responsibility concept and apply CSR practices informally (Jenkins 2006). Usually, networks of SMEs help in identification of social problems and possible solutions to a number of social problems for example, through making a 
cash contribution to the community at large, generating value for the company and responding to the need of the stakeholders (Jenkins 2009a, b).

As mentioned earlier, large firms are engaged in more diversified business activities and implementation of the CSR activities in a structured way. In contrast, the employees of SMEs are more familiar with the core business activities. In large firms, CSR activities are carried out by their accounting or marketing department (Ketola et al. 2009). SMEs often lack such departments and their activities are embedded within everyday business activities. These type of differences in structure and management might affect the ways in which CSR activities are conducted (Ketola et al. 2009). A small number of studies have been conducted on the SMEs and CSR activities (See Handfield et al. 2006; Worthington et al. 2006), however, still this is not clear which activities are better for the SMEs or beneficial (Jenkins 2006) and also in which activates they engage and prioritize (Manuere and Phiri 2016). Generally, SMEs focus on human misery and intensively engage with local society, for example, sponsoring local events and concern for employees' health and satisfaction (Jenkins 2006). SMEs are less interested in social issues in a more integrated or structured way and are not able to identify and manage such issues (Lepoutre and Heene 2006). Employees and owners of SMEs often define CSR broadly, ranging from global to local aspects, like doing business according to the societal ethics, addressing environmental issues, engaging in local issues, maintaining a good relationship with local societal actors and looking after employees (Ketola et al. 2009).

\section{Research Methodology}

Sialkot is famous in the world as a producer of the sports, leather and surgical goods. The industrial sector of Sialkot comprising of sports, surgical and leather is ideal for the proposed study because of its regional and global importance; and critical role in the economic development of Pakistan. Overall the industrial sector of Sialkot contributes to $6 \%$ of the total exports. SME sector of Sialkot is at a tenth position of the country's total export revenue, by selling sportswear products, surgical instruments, leather and leather products to 40 international brands and 60 regional and national brands in Europe and elsewhere (Jamal 2017).

The population frame of this study consists of the registered list of manufacturers and exporters with the Sialkot Chamber of Commerce and Industry, being apex industry association of Sialkot (Khattak and Stringer 2017). For this study, the sample population consists of active manufacturers and exporters of Sialkot in three main industrial subsectors namely sports, surgical and leather. Here it is worth mentioning that not all registered manufacturer and exporters are active manufacturers and exporters. The Sialkot Chamber of Commerce and Industry list contains approximately 8000 registered members.

A qualitative approach was used to study the main research objective of the study because qualitative research allows researchers better explore and underrated under researched phenomenon. In qualitative research, the purposive sampling method is 
prevalent for the selection of units of analysis and collection of information. Purposive sampling is as a process of selecting individuals with similar characteristics to observe similarities and commonalities of patterns (Patton 2002). Through purposive sampling, 80 SMEs were chosen from three industries namely sports, surgical and leather. The sample comprised $51 \%$ managers from sportswear firms with $87 \%$ from the top management and $13 \%$ from the middle level, $32 \%$ was from the leather with $77 \%$ top management and $23 \%$ from the middle level managers, $17 \%$ was managers from the surgical manufacture firms, with $92 \%$ top managers and $8 \%$ from middle level management. Selection of firms in terms of numbers was based on the contribution of each industrial subsector for example sports sector contributes the most, followed by the surgical and leather sector.

Face to face interviews was conducted with the senior managers/executives and owners of SMEs in all the three sub industrial sectors. Most of the SMEs in the industrial sector of Pakistan are family businesses owned and managed by owners. Please refer Appendix at the end of the chapter for the interview questions details. A request letter for scheduling an interview was sent to key informants, requesting them to participate in the interviews. Telephone calls were also made as follow up. With these efforts, only 54 informants agreed to schedule an interview. Out of 54 interviewers, 11 managers were not available in their office for the interviews, hence a total of 43 managers were interviewed for this research.

The data obtained were analysed using qualitative thematic content analysis, which is a descriptive presentation of qualitative data. Analysis was done manually. We used qualitative thematic content analysis prescribed by Anderson (2007). Themes and concepts were derived inductively from the data. Main themes derived from the data have been mentioned in Table 3 of this chapter. Similar themes were grouped together to form categories (constructs) for example, donating funds to different organisation and investing in a social cause were grouped under philanthropy/social construct. Whereas conservation of resources, concerns for waste of production and ecological initiative were grouped under environment category.

\section{Findings and Discussion}

Findings suggest that philanthropy was the key CSR activity performed by most of the firms. SMEs supported their philanthropic activities and considered their moral and legal responsibilities to provide benefit to the people living and community in surroundings of the firms. Findings reveal that managers were actively involved in the philanthropic activities relating to CSR activities. As expressed by one of the informants:

\footnotetext{
We have set agenda on ethical standards to assist the community in the area where we operate because the community has given us the license and supported us to operate the business. We are responsible for meeting the needs of our community. Our firm is participating in providing training to the youth of the local community and share a specific part of our profit to help needy families.
} 
Consistent with the opinions of the other managers in the SME sector, one of the managers expressed his views on philanthropy as follows:

\begin{abstract}
We usually provide money in the form of cash to the needy families, so that they could meet their immediate needs, for example, in case of severe health issues, we bear all medical expense of our employee. Our responsibility is to manage a business in such a way where our firm can earn a good profit and solve social problems.
\end{abstract}

Typically, SMEs were particularly interested in providing cash to poor families for dowry (local type of charity) as a form of philanthropy. Dowry refers to the transfer of resources (monetary and nonmonetary) from the family of a bride to a groom or groom's family (Srinivasan and Bedi 2007). Dowry is one of the major serious social issues in the South Asian region and is declared as a "socially endorsed form of violence in Pakistan" (Bano et al. 2018, 25). As mentioned by one of the informants, "We help our employees by providing marriage grant for their children particularly for their daughters' weddings and cash payments to the orphan families."

Yet another critical factor was that the small firms rarely kept records of their cash giving or philanthropic activities and details of donation receivers. One of the reasons was that the SMEs did not want to make donations and engage in philanthropic activities as a regular practice due to concerns about their economic survival. The owners and managers of the SMEs perceived that the demand for donations and expectations from them would increase if they make it a regular and formal practice. As mentioned by one of the informants "Our priority is to be profitable, and we lack resources to participate in community development programs actively."

Small firms seemed more concerned about their economic survival, whereas medium-sized firms were seen engaged in community development activities more and for their economic surviving at the same time. Small firms faced economic hurdles and constraints to actively engage in the community development programs. Overall there were mixed perceptions of informants from small firms about either it is appropriate for them to engage in charitable activities or philanthropy.

As mentioned by Das and Rangarajan (2017) that the term 'corporate sustainability' is not very familiar to the SMEs and the understanding of the concept does exist among them.

Findings suggest that the main CSR activities of SMEs in the industrial sector of Sialkot fall under four broad dimensions of CSR namely economic, legal, philanthropy (social/ethical) and environment. Although environmental initiatives usually fall under the legal domain of the CSR (Manuere and Phiri 2016) because of the requirements by the importing countries' law, however, we have placed environment dimension as a separate CSR activity or dimension. The main reason is that the empirical data necessitated it to be placed separately from legal because of its importance to the leather sector. Philanthropy has been placed under the social dimension or ethical domain of CSR which pertains to the relationship between business and society (Manuere and Phiri 2016). The economic dimension of the CSR, based on the empirical data, pertains to socioeconomic activities of the firms in a way that takes into account the legal and social aspects seriously. 
We have summarized findings in tabular forms to make it more presentable. Although philanthropy is the major CSR activity which SMEs perform, priorities of SMEs are different. The priorities of the CSR categories are listed in Table 1. By priorities we mean which dimensions of CSR SMEs prefer to undertake based on four major dimensions inductively derived from the data namely economic, environment, legal and philanthropy (social). Informants' views on priorities areas of CSR activities are presented in Table 2. Based on the manager's responses, the SMEs engagement in the CSR practices is categorised in Table 3. Tables are explained in the following paragraphs.

Table 1 reveals that although philanthropy (irregular, undocumented and simple cash giving activities) was the main CSR activity performed by all industrial subsectors in the Sialkot, however, sports sector was at the top. Typically, sports firms were particularly interested in sponsoring the local sports events and provide cash to poor for dowry (explained above). The primary driver behind the involvement of SMEs in the local community and CSR activities was to build the reputational image of the firms and show the concern towards the staff dependents (family and community) and helping them in uplifting social standards. One of the informant from the Sportswear industry mentioned.

\section{We own responsibility to give back to society as part of our business requirement. We are concerned with health and education problems in surrounding community, providing help through free medical camps and providing cash. Our priorities are to provide primary health facilities to old citizens.}

Table 2 portrays that all industrial subsectors were undertaking main CSR activities, but their priorities were different for example, in the sports industry philanthropy was at the heart of CSR activities whereas in the leather industry environmental dimension was the main factor. The difference in the priorities could be due to the nature of industries for example, in the leather industry, the economic survival is

Table 1 Ranking of CSR activities industry wise

Table 2 Category ranking of CSR by firm-specific

\begin{tabular}{l|l}
\hline Category & Firms \\
\hline Philanthropy & Sports \\
\hline Legal & Surgical \\
\hline Economic & Surgical \\
\hline Environment & Leather \\
\hline
\end{tabular}

Source Authors

\begin{tabular}{l|l|l}
\hline Sports & Surgical & Leather \\
\hline Philanthropy & Legal & Environment \\
\hline Legal & Economic & Philanthropy \\
\hline Economic & Environment & Legal \\
\hline Environment & Philanthropy & Economic \\
\hline
\end{tabular}

Source Authors 
Table 3 SMEs involvement in CSR practices

\begin{tabular}{l|l|l}
\hline Category CSR practice & Firms & Managers response (\%) \\
\hline Participation in education development & Sports & 19 \\
\hline Contribution to sports activities & Sports & 35 \\
\hline Contribution in charity & Sports & 40 \\
\hline Fair corporate practices & Surgical & 63 \\
\hline Equal employment opportunities & Surgical & 23 \\
\hline Concerned with poverty problems & Surgical & 53 \\
\hline Participation in human right activities & Surgical & 13 \\
\hline Contribution in community development & Surgical & 35 \\
\hline Concerned with social obligation & Leather & 27 \\
\hline Concerned with the waste of production & Leather & 36 \\
\hline $\begin{array}{l}\text { Concerned with hazardous effect on } \\
\text { environment }\end{array}$ & Leather & 29 \\
\hline Contribution to ecological initiative & Leather & 22 \\
\hline
\end{tabular}

Source Authors

dependent on compliance with the environmental standards. The polluting nature of the leather industry requires their main buyers in the west to outsource from firms complying with the environmental standards as mentioned by one of the informants "We believe that our existence is because of that we adhere and comply with the ethical standards set by the buyers [customers mostly companies in developed countries] and legal aspects". Here it is worth mentioning that the economic survival is the main requirement for all SMEs but economic survival itself depends on meeting the legal, environmental and social (philanthropic activities) standards in surgical, leather and sports industry respectively. A very recent study supports our findings that firms in the leather industry in Sialkot undertake environmental initiatives due to the regulations in the buyers' countries (Wahga et al. 2018). The leather manufacturing is related to environmental pollution caused by tannery wastes produced during leather processing processes and as such some countries (major buyers) have devised and implemented regulations related to production and import of leather products with regard to the hazardous substance (Dixit et al. 2015). Similarly, Table 2 also portrays that for the sports subsector environmental dimension of CSR is least important which could be due to the reason that the environmental impact of the manufacturing of sporting goods, in particular, football (the main product manufactured in the sector), is not detrimental. Our findings are supported by a study where a low level of involvement in the environmental initiatives by the sports firms in Sialkot was attributed to the low or negligible water consumption and less waste created because major waste was bought by raw material suppliers and recycled (Khattak and Stringer 2017). 
Table 3 has been derived from the data in order to capture main CSR activities actually performed by each of the industrial subsector and it clearly shows that philanthropy is the main activity performed by each of the sector in the form of participation in education development, charity, tackling poverty problems, participation in human right activities contribution in community development etc. However, ecological initiatives are at the forefront of the leather industry; and legal concerns in the surgical industry.

\section{Conclusion}

Findings in this study highlighted CSR practices perceived essential and genuinely viewed crucial by the managers of SMEs. This study contributes to the CSR literature by identifying philanthropy as a most important CSR activity among SMEs in the industrial sector of Sialkot in Pakistan. Overall generally, findings are in line with the Carroll's (1979) categorisation of CSR dimensions and all dimensions are applicable to the SME sector in Sialkot. However, main dimensions of CSR in the context of Sialkot were social (philanthropy), economic, legal and environment. Furthermore, there is difference in terms of priorities and applicability which is very much dependent on the nature of the industry and issues related to the industries. The challenge for the SMEs due to irregular philanthropic activities is developing philanthropic approach that can truly deliver sustainability benefits to society and create value for both society and business. To implement feasible and beneficial CSR practices, managers should understand the social needs of their society and design the CSR activities according to the needs of the local community. As mentioned by Manuere and Phiri (2016) that the meaning of CSR is related to the major CSR activities undertaken by SMEs in a specific context and hence, SMEs that indulge in donating money and goods to needy people will define CSR as donations in cash.

\section{Future Research}

Future research can adopt comparative quantitative studies to understand and explain about the key CSR activities by the SMEs in various industrial sectors and in various geographical locations. Future research may also examine the relationship between CSR activities and the internationalisation processes of SMEs. One limitation of the study is that the data were collected from the manufacturing sectors only. Future researchers could extend the findings of the present study to SMEs in service sectors. 


\section{Appendix: Interview Questions}

- What CSR activities are important for your firm?

- What CSR activities do you prefer as a manger and why?

- Did you have any pre-defined CSR goals?

- Why would you initiate any CSR project?

- Why are you involved in specific CSR activities and which areas you have invested in?

- What are the key CSR activities in which your firm is engaged?

- What CSR practices your firm would prefer to engage in?

\section{References}

Anderson, R. (2007). Thematic content analysis (TCA). Descriptive presentation of qualitative data. Retrieved from https://s3.amazonaws.com/academia.edu.documents/36098984/Thematic_Conte nt_Analysis_manuscript.pdf.

Arli, D. I., \& Lasmono, H. K. (2010). Consumers' perception of corporate social responsibility in a developing country. International Journal of Consumer Studies, 34(1), 46-51.

Aupperle, K. E., Simmons III, F. B., \& Acar, W. (1990). An empirical investigation into how entrepreneurs view their social responsibilities. In 1990 Proceedings of the Academy of Management (pp. 154-156).

Awan, U., Kraslawski, A., \& Huiskonen, J. (2017). Understanding the relationship between stakeholder pressure and sustainability performance in manufacturing firms in Pakistan. Procedia Manufacturing, 11, 768-777.

Bano, S., Asif, A. F., Saadat, S., \& Muhammad, N. (2018). Socioeconomic factors of depression among females visiting outpatient clinic in district Ghizar, Gilgit-Baltistan, Pakistan: A pilot study. Khyber Medical University Journal, 10(1).

Blindheim, B. T., \& Langhelle, O. (2010). A reinterpretation of the principles of CSR: A pragmatic approach. Corporate Social Responsibility and Environmental Management, 17(2), 107-117.

Business for Social Responsibility. (2003). Overview of Corporate Social Responsibility. http:// www.bsr.org/BSRResources/IssueBriefDetail.cfm?DocumentID=48809. May 10, 2018.

Carroll, A. B. (1979). A three-dimensional conceptual model of corporate performance. Academy of Management Review, 4(4), 497-505.

Carroll, A. B. (1991). The pyramid of corporate social responsibility: Toward the moral management of organizational stakeholders. Business Horizons, 34(4), 39-48.

Dahlsrud, A. (2008). How corporate social responsibility is defined: An analysis of 37 definitions. Corporate Social Responsibility and Environmental Management, 15(1), 1-13.

Das, M., \& Rangarajan, K. (2017). Corporate sustainability as a business strategy in SMEs-A literature review in the emerging market context. In Proceedings of International Conference on Strategies in Volatile and Uncertain Environment for Emerging Markets (pp. 505-511), July 14-15. Indian Institute of Technology Delhi, New Delhi.

Davies, I. A., \& Crane, A. (2010). Corporate social responsibility in small-and medium-size enterprises: Investigating employee engagement in fair trade companies. Business Ethics, 19(2), $126-139$.

Deakins, D., \& Freel, M. (1998). Entrepreneurial learning and the growth process in SMEs. The Learning Organization, 5(3), 144-155.

Dixit, S., Yadav, A., Dwivedi, P. D., \& Das, M. (2015). Toxic hazards of leather industry and technologies to combat threat: A review. Journal of Cleaner Production, 87, 39-49. 
Duan, Y., Mullins, R., \& Hamblin, D. (2001). Training for e-commerce success in SMEs. In Managing Information Technology in Small Business: Challenges and Solutions: Challenges and Solutions (p. 334). IGI Global.

Hadjimanolis, A. (2017). A barriers approach to corporate social responsibility (CSR) adoption in SMEs: The case of Cyprus. In W. Visser, M. McIntosh, \& C. Middleton (Eds.), Corporate citizenship in Africa. Abingdon: Taylor \& Francis.

Handfield, R. B., Krause, D. R., Scannell, T. V, \& Monczka, R. M. (2006). Avoid the pitfalls in supplier development. In Supply chains and total product systems: A reader (Vol. 58).

Jamal, N. (2017). Sialkot's share in exports. Dawn. Retrieved from https://www.dawn.com/news/1 330226.

Jenkins, H. (2006). Small business champions for corporate social responsibility. Journal of Business Ethics, 67(3), 241-256.

Jenkins, H. (2009a). A 'business opportunity'model of corporate social responsibility for small-and medium-sized enterprises. Business Ethics: A European Review, 18(1), 21-36.

Jenkins, H. (2009b). A 'business opportunity' model of corporate social responsibility for smalland medium-sized enterprises. Business Ethics-a European Review, 18(1), 21-36.

Ketola, T., Blombäck, A., \& Wigren, C. (2009). Challenging the importance of size as determinant for CSR activities. Management of Environmental Quality: An International Journal, 20(3), 255-270.

Khattak, A., Haworth, N., Stringer, C. A., \& Benson-Rea, M. (2017). Is social upgrading occurring in South Asia's apparel industry? Critical Perspectives on International Business, 13(3).

Khattak, A., \& Stringer, C. (2017). Environmental upgrading in Pakistan's sporting goods industry in global value chains: A question of progress? Business \& Economic Review, 9(1), 43-64.

Khattak, A., Stringer, C., Benson-Rea, M., \& Haworth, N. (2015). Environmental upgrading of apparel firms in global value chains: Evidence from Sri Lanka. Competition \& Change, 19(4), $317-335$.

Laskar, N., Maji, S. G., \& Ortiz-Martinez, E. (2016). Corporate sustainability reporting practices in India: myth or reality? Social Responsibility Journal, 12(4).

Laudal, T. (2011). Drivers and barriers of CSR and the size and internationalization of firms. Social Responsibility Journal, 7(2), 234-256.

Lepoutre, J., \& Heene, A. (2006). Investigating the impact of firm size on small business social responsibility: A critical review. Journal of Business Ethics, 67(3), 257-273.

Manuere, F., \& Phiri, M. (2016). The relationship between CSR meaning and CSR practices: The case of SMES. Corporate Ownership \& Control, 13(4), 103-109.

Matten, D., \& Moon, J. (2008). 'Implicit' and 'explicit' CSR: A conceptual framework for a comparative understanding of corporate social responsibility. Academy of Management Review, A, 33(2), 404-424.

Patton, M. Q. (2002). Qualitative research \& evaluation methods (3rd ed.). Thousand Oaks: Sage Publications.

Perrini, F., Russo, A., \& Tencati, A. (2007). CSR strategies of SMEs and large firms. Evidence from Italy. Journal of Business Ethics, 74(3), 285-300.

Shiozawa, S. (1995). Philanthropy as a corporate strategy. Japanese Economic Review, 46(4), 367-382.

Srinivasan, S., \& Bedi, A. S. (2007). Domestic violence and dowry: Evidence from a South Indian village. World Development, 35(5), 857-880.

State Bank of Pakistan. (2013). Prudential regulations for small \& medium enterprise infrastructure. Karachi: Housing \& SME Finance Department, Karachi.

Turyakira, P. K. (2018). Corporate social responsibility activities that influence customer loyalty of SMEs. International Journal of Business and Management, 13(6), 255-266.

Waddock, S. (2004). Parallel universes: Companies, academics, and the progress of corporate citizenship. Business and Society Review, 109(1), 5-42. 
Wahga, A. I., Blundel, R., \& Schaefer, A. (2018). Understanding the drivers of sustainable entrepreneurial practices in Pakistan's leather industry: A multi-level approach. International Journal of Entrepreneurial Behavior \& Research, 24(2), 382-407.

Worthington, I., Ram, M., \& Jones, T. (2006). Exploring corporate social responsibility in the UK Asian small business community. Journal of Business Ethics, 67(2), 201-217. 


\section{Author Queries}

Chapter 15

\begin{tabular}{|c|l|c|}
\hline Query Refs. & Details Required & Author's response \\
\hline AQ1 & $\begin{array}{l}\text { Please check and confirm if the authors and their respective affil- } \\
\text { iations have been correctly identified. Amend if necessary. }\end{array}$ & \\
\hline AQ2 & $\begin{array}{l}\text { As chapter-wise Keywords are mandatory, please provide the Key- } \\
\text { words }\end{array}$ & \\
\hline AQ3 & $\begin{array}{l}\text { Kindly note that the reference 'Dahlsrud (2006)' has been changed } \\
\text { to 'Dahlsrud (2008)' so that this citation matches the list. }\end{array}$ & \\
\hline AQ4 & $\begin{array}{l}\text { Please check and confirm the edit made in the sentence 'Tables } \\
\text { are explained ...'. }\end{array}$ & \\
\hline
\end{tabular}




\section{Please correct and return this set}

Please use the proof correction marks shown below for all alterations and corrections. If you wish to return your proof by fax you should ensure that all amendments are written clearly in dark ink and are made well within the page margins.

\begin{tabular}{|c|c|c|}
\hline Instruction to printer & Textual mark & Marginal mark \\
\hline Leave unchanged & ... under matter to remain & ( $)$ \\
\hline $\begin{array}{l}\text { Insert in text the matter } \\
\text { indicated in the margin }\end{array}$ & $\Lambda$ & $\begin{array}{l}\text { New matter followed by } \\
h \text { or } h \otimes\end{array}$ \\
\hline Delete & $\begin{array}{l}\text { I through single character, rule or underline } \\
\text { or }\end{array}$ & $\sigma$ or $\sigma / 2$ \\
\hline $\begin{array}{l}\text { Substitute character or } \\
\text { substitute part of one or } \\
\text { more word(s) }\end{array}$ & I through letter or & $\begin{array}{l}\text { new character / or } \\
\text { new characters / }\end{array}$ \\
\hline Change to italics & — under matter to be changed & $\leftarrow$ \\
\hline Change to capitals & $\equiv$ under matter to be changed & $\equiv$ \\
\hline Change to small capitals & $=$ under matter to be changed & $=$ \\
\hline Change to bold type & $\sim$ under matter to be changed & $\sim$ \\
\hline Change to bold italic & $\bar{\sim}$ under matter to be changed & 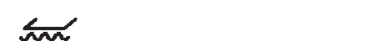 \\
\hline Change to lower case & Encircle matter to be changed & $\Rightarrow$ \\
\hline Change italic to upright type & (As above) & \\
\hline Change bold to non-bold type & (As above) & nor \\
\hline Insert 'superior' character & $\begin{array}{l}/ \text { through character or } \\
\alpha \text { where required }\end{array}$ & $\begin{array}{l}y^{\prime} \text { or } y \\
\text { under character } \\
\text { e.g. } y^{2} \text { or } y^{2}\end{array}$ \\
\hline Insert 'inferior' character & (As above) & $\begin{array}{l}\lambda \\
\text { over character } \\
\text { e.g. } \hat{\Sigma}\end{array}$ \\
\hline Insert full stop & (As above) & $\odot$ \\
\hline Insert comma & (As above) & , \\
\hline Insert single quotation marks & (As above) & $\begin{array}{l}\dot{y} \text { or } \dot{x} \text { and/or } \\
\dot{y} \text { or } \dot{y}\end{array}$ \\
\hline Insert double quotation marks & (As above) & $\begin{array}{l}\ddot{y} \text { or } \ddot{x} \text { and/or } \\
\ddot{y} \text { or } \ddot{x}\end{array}$ \\
\hline Insert hyphen & (As above) & 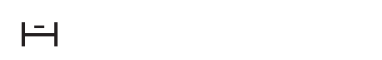 \\
\hline Start new paragraph & 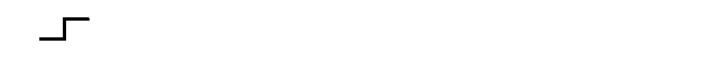 & 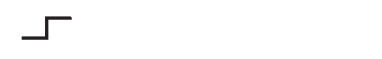 \\
\hline No new paragraph & 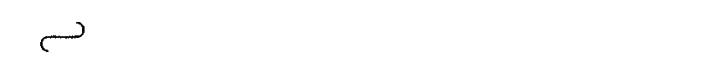 & 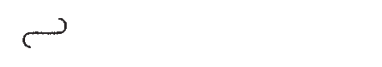 \\
\hline Transpose & $\sqcup$ & $\sqcup$ \\
\hline Close up & linking $\bigcirc$ characters & \\
\hline $\begin{array}{l}\text { Insert or substitute space } \\
\text { between characters or words }\end{array}$ & $\begin{array}{l}\text { I through character or } \\
\Lambda \text { where required }\end{array}$ & \\
\hline $\begin{array}{l}\text { Reduce space between } \\
\text { characters or words }\end{array}$ & $\begin{array}{l}\text { between characters or } \\
\text { words affected }\end{array}$ & $\uparrow$ \\
\hline
\end{tabular}

